Article

\title{
Becoming a Sustainable Organization: Focusing on Process, Administrative Innovation and Human Resource Practices
}

\author{
Hyejin Cho ${ }^{1}$, Pyoungsoo Lee ${ }^{2, *}$ and Choong Ho Shin ${ }^{3, *}$ \\ 1 Department of Business Administration, Korea University, Anam-ro 145, Seoul 02841, Korea \\ 2 Department of Business Administration, Kyonggi University, Gwanggyosan-ro 154-42, Suwon 16227, \\ Gyeonggi, Korea \\ 3 Department of IT Management, Kyungmin University, Seobu-ro 545, Euijeongbu 11618, Gyeonggi, Korea \\ * Correspondence: pyoungsoo@kgu.ac.kr (P.L.); cshin24@kyungmin.ac.kr (C.H.S.); \\ Tel.: +82-31-249-9457 (P.L.); +82-31-828-7170 (C.H.S.)
}

Received: 29 May 2019; Accepted: 17 June 2019; Published: 28 June 2019

\begin{abstract}
Despite the importance of constant product improvement to becoming a sustainable organization, the relationship between different types of innovation and new product development has received little attention. This article contributes to prior research by proposing a necessary condition for successful product development, which increases organizational sustainability. While it has been widely argued that technological innovation is an important factor for new product development, we contribute by illustrating the importance of process and administrative innovation, which changes an organization's way of doing business. By analyzing survey responses from 2127 Korean firms, we empirically demonstrate that process and administrative innovation increase the likelihood of achieving new product development goals. Our findings also show that innovation-supporting human resource practices such as talent development programs and work autonomy increase the effectiveness of process and administrative innovations. Overall, we suggest that organizations are able to achieve a sustainable presence in the product market when they constantly innovate the way they run themselves. Additionally, in order to manage such innovation, organizations should nurture a creative environment by devising effective, innovation-supporting human resource practices.
\end{abstract}

Keywords: process innovation; administrative innovation; product development; human resource policies; organizational sustainability

\section{Introduction}

Over the past twenty years, the topic of organizational sustainability has received considerable attention from management researchers as it focuses on an organization's long-term success instead of short-term financial performance [1]. It has long been argued that the sustainability of a firm is supported by innovation, or the potentially transformational force that challenges existing practices and generates new processes [2]. By definition, innovation is "the international introduction and application within a role, group or organization of ideas, processes, products or procedures, new to the relevant unit of adoption, designed to significantly benefit the individual, the group, the organization and wider society" [3] (p. 9). Both academics and practitioners continue to argue that innovation is one of the key elements through which organizations, institutions, communities, and countries can implement change and become more sustainable [4], and sustainable product development is one of the most important elements in achieving long-term prosperity and growth [5]. New product development is generally considered to be a necessary factor for surviving today's fast-paced market environment [6]. 
Improving product performance also benefits consumers and society, which, ultimately, leads to sustained market competitiveness for firms.

The concept that always appears when discussing the performance of new product development is technological innovation, and prior research has primarily emphasized the role of technological innovation [7-10]. Technology drives innovation, in general, and the performance of innovation is often interpreted as the performance of new product development. In the academic field, technology is also recognized as an important factor in the development of new products because it enables the creation of new products $[10,11]$. While it is clear that technical ability is important in new product development, not all companies with such advanced technology develop new products successfully. Therefore, it is necessary to pay attention to factors other than technology in terms of organizational internal aspects. We focus on product innovation from the perspective of the processes and organizational structures that an organization has, rather than directly linking the technology to the performance of new product development.

In this study, we propose that organizational innovation, that is, process and administrative innovation, can also be viewed as a means of developing valuable resources, as organizational processes/systems may also be important to achieving sustainable competitive advantage. Based on prior research that highlights the relationship between an organization's innovative capability and new product development [12-16], we first propose that process innovation aimed at creating production efficiency will promote the development of new products. A more efficiently managed process can support the emergence of new products as this environment is better suited to the creation and production of advanced goods. Secondly, administrative innovation such as improvements in information management and work efficiency is likely to support employees by providing a more efficient management system. We expect that such innovation within organizational systems will promote the development of new products.

Lastly, we test the role of innovation related to human resource (HR) practices, as human resources are a key factor of innovative performance [17]. Attempts by firms to innovate their current environments are likely to be successful when employees responsible for running innovative processes are motivated; hence, we predict that proper HR practices improve the outcomes of innovation attempts. Given the important role of talent, that is, key personnel, in leading and completing innovation activities, we first test whether HR programs that support talent boost the effectiveness of innovation in organizational processes and administration. We also analyze whether the effectiveness of innovation increases when employees are given increased work autonomy. As innovation leads to the enhancement of current activities or processes by allowing and absorbing new approaches and standards, we expect that increased work autonomy will help organizations achieve higher levels of innovation.

Using survey responses from 2127 Korean manufacturing firms, we test the effect of administrative and process innovation on the probability of new product development. We also analyze whether HR practices positively moderate the effect of innovation on new product development. Our empirical findings suggest that both process and administrative innovation enhance the likelihood of new product development. This relationship is also strengthened in the presence of HR practices related to talent management and work autonomy. However, work autonomy has an insignificant moderating effect on the relationship between administrative innovation and new product development.

This study contributes to the literature on innovation by examining how a firm's attempt to innovate its current organizational system or processes matters in terms of new product development. First, while prior research has extensively explored the role of technological innovation, in business practices or processes, in creating sustainable growth in the industry $[18,19]$, we shed light on the relationship between other types of innovation and firm performance, which we understand less [20]. Our findings suggest that the sustainable competitiveness of firms in the market is ultimately dependent upon the innovation of status quo internal systems, that is, business structures and processes. Such innovation can shape a supportive environment for the sustainable development of new products. Thus, 
our findings extend the existing literature by showing that the effect of innovation in organizational management in general, i.e., process and administrative innovation also has a significant impact on new product development. Second, this study examines the joint effects of innovation and HR practices on new product development. Our findings imply that a firm's innovation strategy for pursuing sustainable growth should be employed in tandem with practices that support the people who are actually implementing and operating these innovation processes.

The remainder of this paper is organized as follows. First, the second section provides a review of the literature related to new product development and the research questions we want to address. In the third section, the data and method used for the empirical analysis are explained. The third section will also present results, and in the final section, the main conclusions are presented, and implications are suggested.

\section{Literature Review and Hypothesis Development}

\subsection{Literature Review}

Over the past three decades, new product development issues have received considerable attention in various business fields, and they have become an important research topic. In the field of operations and supply chain management, as business organizations continue to make efforts to develop new products, with a low success rate, most of the product development literature has focused on the overall process of product development or key success factors affecting product outcomes (e.g., [12,21-28]). The suggestion that project-specific factors affect the outcomes of new product development activities has been widely analyzed $[10,11,29,30]$. Also, a firm's performance in terms of new product development is believed to be positively related to third-party suppliers [31-34], or collaboration with customers [35-39]. As Joshi and Sharma [40] mentioned, researchers argue that developing new products using only internal knowledge is no longer sufficient to maintain or enhance competitive status. It is clear that innovation within an organization is a prerequisite for a strong performance in terms of new product development. Hence, we expand the discussion by attempting to identify the role of innovation within an organization in achieving better product development performance. This, in turn, will provide a more integrated view of new product development. In a recent study by Cooper [10], three key success factors are identified from prior studies that explain new product development performance. These success factors can be found at three different levels: (1) the individual project level, (2) business level, and (3) systems and methods level. As we are primarily concerned with research related to the overall management of an organization, rather than individual product development projects, we focused on the second and third categories identified by Cooper [10]. While prior research has analyzed "methods and systems" that are directly relevant to the product development process itself, we extend this view by investigating the effect of organizational-level methods and systems rather than focusing solely on the product development process level.

Also, organizational studies have shown how appropriate organizational management or HR practices can nurture the innovative environment (e.g., [8,41,42]). For instance, Haneda and Ito [42] connect the organizational and HR practices to product/process innovation and Mokhber et al. [43] show effect of leadership style on new product development. However, how an organization can achieve its new product development goals through innovations in organizational management has been under-researched. While prior organizations literature view that organization management practices are static and innovation take place only in the product development, we focus on whether attempts by firms to innovate organizational management itself influence new product development. Organization studies have suggested that an organization's sustained performance and growth is determined by the organization's ability to employ new practices to rejuvenate its strategy, structure, and processes [44-47]. Hence, we attempt to propose a model that increases our understanding of how innovations in organizational management, that is, processes or administrative practices, change the likelihood of successfully introducing a new product. 
In proposing the relationship between organizational innovation and new product development, we extend the argument by integrating the role of HR practices. The effectiveness of innovation attempts can differ depending on whether an organization's HR practices motivate employees and nurture an innovative environment. Human resource management (HRM) research emphasizes the relationship between HR practices and organizational performance; a firm must possess a good system for ensuring the effective utilization of human resources in order to develop and maintain competitiveness [48]. Especially in today's knowledge-based economy, one of the most important antecedents of sustainable competitive advantage is acquiring and retaining talented personnel [49]. HR practices are the primary means by which firms achieve organizational goals as these practices shape the skills, attitudes, and behavior of employees [50,51]. HR practices that emphasize extensive training and development are regarded as a necessary step in product innovation [52]. While prior research has highlighted the role of HR practices in achieving innovation, this research attempts to analyze how HR practices strengthen the impact of introduced innovation on new product development. While a firm may attempt to change existing processes and norms, such innovation attempts will lead to actual new product development only when employees are supported by strong HR practices that allow them to utilize introduced innovation in the organization. Hence, our study aims to contribute to the HR literature by demonstrating the important role of HR practices in intensifying the effectiveness of innovation on new product development.

\subsection{Hypothesis Development}

\subsubsection{Relationship between Process Innovation and New Product Development}

Process innovation is defined as the introduction of new elements into an organization's production or service operations to produce a product or render a service [53-55]. More specifically, it refers to alterations to processes, through significant changes in technology, equipment, and/or software, that are intended to reduce costs or improve quality [56]. Since process innovation is primarily efficiency driven, it requires a firm to apply technology to improve the performance of new product development [57]. In other words, process innovation is crucial for product innovation, which translates into the successful introduction of new products [58].

While it is unquestionable that new product development and process innovation affect one another, their pattern of interaction is unclear [59]. We argue that by improving their processes, organizations can strengthen their product development capabilities. A more efficient process better supports the emergence of new products as employees can enjoy an efficient usage of resources.

Therefore, we suggest the following hypothesis under the premise that success in new product development depends on a firm's attempts to improve the efficiency of its current processes.

H1. Process innovation increases the likelihood of new product development.

\subsubsection{Relationship between Administrative Innovation and New Product Development}

Administrative innovation aims to improve an organization's capability by changing its organizational structure, and administrative or work processes [54,58]. Cummings and Srivastava [60] explain that it is the innovation of communication and exchange among people with the same goal or task, or between the environment and people. For instance, improving online connectivity and knowledge sharing among different departments may allow employees to easily utilize highly accumulated knowledge without hassle. Another example of this type of innovation is when a firm attempts to innovate its current operational flow by partnering with external parties. Such utilization of external resources takes place when a firm perceives that certain processes can be more efficiently handled by others. In this way, an organization can improve the efficiency of resource allocation by focusing its limited resources on its core strength. Administrative innovation is closely related to the 
improvement of the management of an organization, which in turn leads to a higher quality and more efficient workflow.

We expect that administrative innovation supports firms in achieving new product development goals for several reasons. First, administrative innovation is needed to adapt to the changing marketplace and to create a new environment, such as by introducing new products or services. Damanpour and Evan [61] emphasize the importance of increasing system effectiveness to match new market requirements by providing the following example. For instance, a library that replaces a card catalog system with a computer-based cataloging system must establish a new administrative structure that is able to serve this new type of data management, and it must create new work procedures with new roles for employees. Without such a change in the organization, the library cannot offer timely and advanced services. Likewise, in order for firms to achieve new product development, administrative innovation is needed to support the emergence of new products.

Second, administrative innovation improves organizational learning capability and provides employees with a better environment that enables them to focus their time and effort on the core issues related to new product development. The development of a new product is a complicated process that requires searching for market information and preparing to meet new market trends [62]. Hence, increasing firm efficiency through administrative innovation will lead to better knowledge management, for example, efficient information transfer increases learning opportunities and the level of knowledge sharing among employees [63]. Such an improved ability to adapt and reconfigure resources and capabilities can be regarded as a sustainable competitive advantage [64,65].

Based on the above arguments, we propose the following hypothesis:

H2. Administrative innovation increases the likelihood of new product development.

\subsubsection{Moderating Effect of HR Practices}

HRM research emphasizes the relationship between HR practices and organizational performance. A firm must possess a good system that ensures the effective utilization of human resources in order to develop and maintain competitiveness [48]. In particular, it has been largely suggested that the effectiveness of innovation is determined by a supportive, innovative climate, and related capabilities are needed [66]. Hence, an innovation-enhancing HR practice is critical. As an appropriate HR system suited to the organizational context contributes to competitive success [52], an exploration of which HR practices increase the effectiveness of innovation within an organization is needed. Prior research has highlighted the importance of (1) functions and (2) motivators in higher innovative performance (e.g., [67]). First, functions that support innovative attempts is majorly handled by talents within the organization. Roberts and Fusfeld [68] described that critical functions, e.g., idea generating, entrepreneuring, or project leading are essential, and the employees who provide such critical functions account for a fairly small part of the total employees [69]. There has been a growing popularity of talent management as it has been suggested as a contributor to an organization's sustainable competitive advantage [70]. Second, employees are often motivated by the work environment factors which can increase the personal satisfaction, and one of the most important factors is the ability and freedom to pursue ideas of greatest interests of the workers [69]. A controlling management style is likely to reduce employee's motivation and lower creative performance, which in turn reduce creativity and innovation [71]. Contrarily, work autonomy which nurtures the environment in that employees can address problems and opportunities that arise contemporaneously [72,73]. These advantages of task autonomy and employee empowerment are most beneficial for organizations that are attempting innovate, as task autonomy foster creativity and innovation and provide ground for exploratory learning [74]. Furthermore, the innovation process involves intrinsic uncertainty, which is most effectively dealt with by allowing employees to have the greater flexibility in making decisions $[75,76]$. In this regard, we suggest that two types of HR practices, related to talent management 
and work autonomy, contribute to new product development by supporting innovative activities within an organization.

First, given the importance of talent in innovative activities and new product development, an HR program that supports talent is expected to strengthen innovation-related pursuits. Firms are increasingly facing a War for Talent, as attracting and retaining talent provides firms with sustainable competitiveness [77]. Huselid at al. [78] argue that there is disproportionate importance placed on a firm's ability to execute some parts of its strategy and wide variability in the quality of work displayed among employees in different positions. While the term talent does not have a widely accepted definition, it is often reported that firms, in practice, define talent as executives, directors, or A-player managers in all functions, or future business leaders with more strategic capabilities than just skills related to operational excellence [79]. One of the most adopted definitions for talent management is "activities and processes that involve the systematic identification of key positions that differentially contribute to the organization's sustainable competitive advantage, the development of a talent pool of high-potential and high-performing incumbents to fill these roles, and the development of a differentiated human resource architecture to facilitate filling these positions with competent incumbents, and to ensure their continued commitment to the organization," by Collings and Mellahi [70] (p. 305). Talent management is closely related to the improvement of operational excellence since a firm's talent is comprised of key decision makers who can handle complex decision processes [80]. Talent provides creative ideas and knowledge creation and enables organizations to improve competitiveness [81-83]. Managing critical talent within the organization is especially important for firms that face uncertainties as talent is most needed when firms have important strategic decisions to make. Joyce and Slocum [84] find that an organization's particular strategic situation increases the need for talent management as it allows the organization to achieve its highest levels of performance. Hence, we expect that the innovation process will be handled more efficiently by firms that have practices that support talent.

Second, it is necessary for firms to respond and adapt to the rapidly changing environment in a timely manner, and this requires flexibility within the organization [71]. It is often argued that the level of exploration is closely related to the level of autonomy given to employees as employees that have new ways of thinking are likely to show autonomous characteristics [85]. Mumford and Gustafson [86] and Zhu [87] highlights the role of autonomy within an organization in facilitating creativity. Higher levels of autonomy allow employees to utilize the best methods and procedures to achieve innovative goals. Prior studies provide empirical evidence of the effects of autonomy on creative performance (e.g., [88-90]). As creativity is affected by autonomy, allowing employees to decide for themselves how best to explore and achieve a goal, we expect that HR practices that support work autonomy will support employees in fully utilizing the new environment that process and organization innovation provides.

Based on the above argument, we propose that talent development and work autonomy will positively moderate the influence of innovation on new product development, leading to the following hypotheses:

H3. Existence of a talent development program strengthens the positive relationship between process/administrative innovation and new product development.

H4. Higher work autonomy strengthens the positive relationship between process/administrative innovation and new product development.

\section{Research Design}

\subsection{Sample}

In order to test the suggested theoretical model (as shown in Figure 1), we utilize the Workplace Panel Survey 2015 [91], a statistical survey approved by the national government and conducted by the 
Korean Labor Institute, a government-funded policy research body. The sample represents workplaces in Korea using stratified sampling and surveys of HR personnel and employee representatives. We only include data obtained from private sector firms, so the final sample consists of 2127 firms.

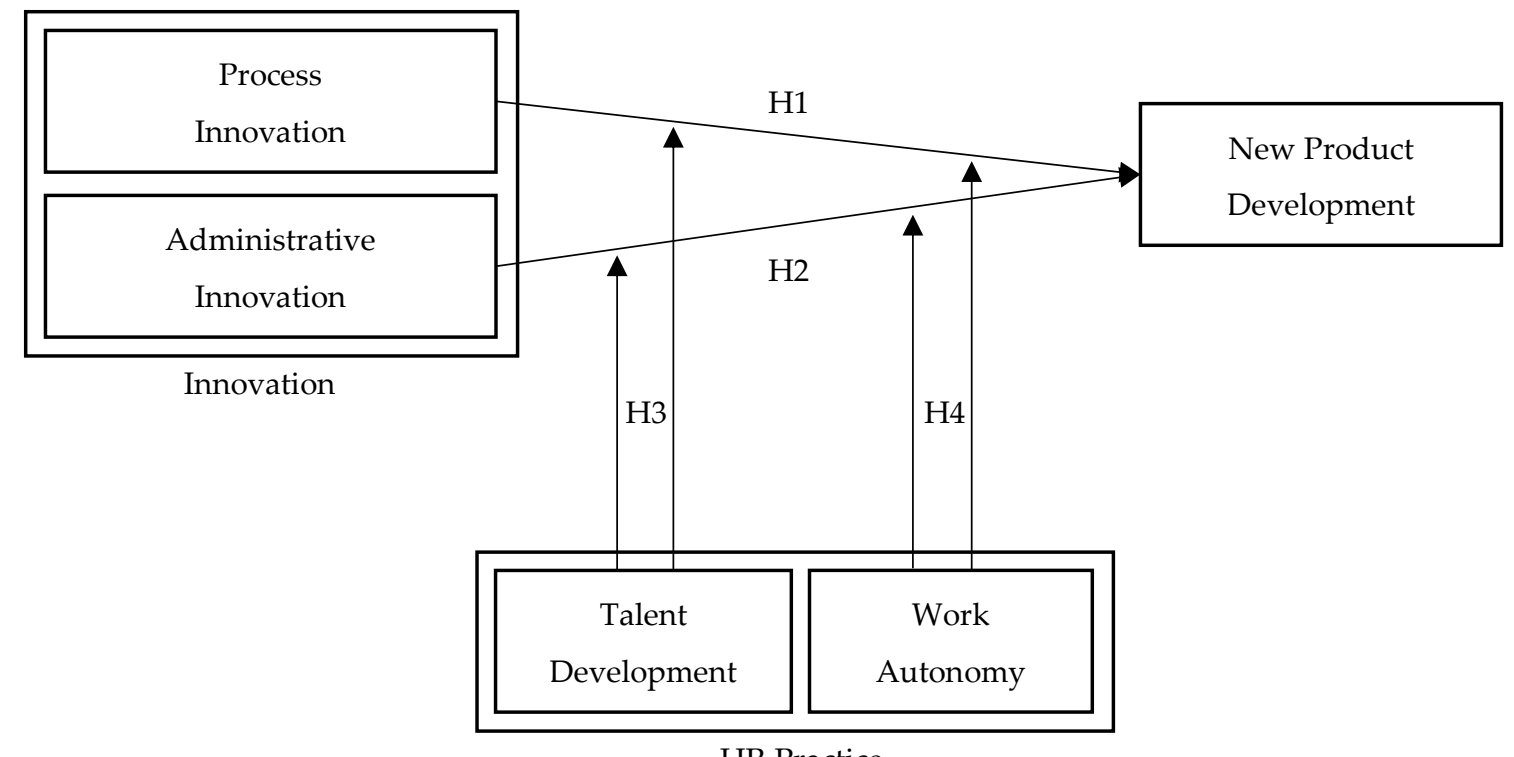

HR Practice

Figure 1. Theoretical research model.

\subsection{Measures}

The dependent variable is New Product Development, which reflects the development of an entirely new, or newly enhanced, product by utilizing the response to the following question: "Did your workplace or company, via innovations of \{product/service\}, launch a new \{product/service\} or a newly improved \{product/service\} in the market?" [91]. An example of a new product innovation is developing a digital camera from a film camera or introducing real-time mobile information delivery, from internet information delivery. The innovations mentioned in the survey responses are innovations in products/services that have been commercialized within the past year, based on the point of view of the organization in question.

Process Innovation is an independent variable that captures significant enhancements in manufacturing logistics or retailing delivery that achieved cost reductions or quality enhancement. We utilize the response to the following question: "Did your workplace implement process innovation last year?" [91]. In this definition of process innovation, only the adoption of manufacturing processes is applicable here. For example, new manufacturing methods (Enterprise Resource Planning, Just-In-Time, etc.); production automation; radio-frequency identification (RFID) on logistics; and IT technology for procurement, accounting, and maintenance are types of process innovation that may have been adopted.

Administrative Innovation is another independent variable that reflects improvements in organizational capability, such as new work processes that improve the quality or efficiency of workflow, new methods of knowledge management, and external relationship improvements. To measure this, we utilize the following question: "Did your workplace implement administrative innovation last year?" This may include, for example, a significant improvement in information collection and sharing within a company, trial administrative changes to improve work flexibility and efficiency, partnering with other companies, and outsourcing. Such innovation should be the result of a management decision and have been executed in a manner that is in line with administrative innovation.

Talent Program is a moderating variable that shows the existence of an HR program that supports talent. Talent can be defined as employees who are professional experts in each job function (research and development, marketing, finance, etc.) or high performers. It is a dummy variable that shows the value of 1 when a firm has a separate personnel management policy to secure, develop, and retain 
talent, and 0 otherwise. Such a firm will have clearly distinguished talent from workers in general. Work Autonomy is a moderating variable that captures the level of autonomy given to the major teams or work groups in making decisions (e.g., working method, the pace of work, recruitment, or training). The value of Work Autonomy varies from 1 to 4 , with 4 indicating the highest level of autonomy.

While analysis based on survey allows researchers to construct variables reflecting the theoretical domain, our variable is reflecting the response to a single questionnaire. It is because our sample was extracted from a survey executed by a government-funded policy research body with the aim to understand a firm's behaviors and relevant outcomes. Hence, the questionnaire itself had not been formulated with the academic perspective, and the multiple items are not included to understand a higher theoretical domain. However due to the nature of the research institution, this survey provides a higher response rate and allows us to find the more generalized relationship between organizational innovation, HR practices, and product innovation.

To control for other firm effects, we utilized various firm-specific variables. As a firm size implies the degree of resources availability has been suggested to have an influence on the level of innovation [92] or new product introduction [93], we included Firm Size defined as the natural logarithm value of total assets following Hoskisson et al. [94]. As innovation opportunity can be utilized with financial resources [95], we included two variables related to a firm's financial status. Return on assets (ROA) is defined as net income divided by total assets following Santos et al. [96] and Hoskisson et al. [94]. Debt Ratio is defined as total debts divided by total assets following Aghion et al. [97]. Sales Growth is defined as the percentage change in total sales compared to the prior year's total sales figure following Uhlaner et al. [98]. It is to control the relationship between sales growth and new product development [98]. All control variables were lagged at $\mathrm{t}-1$ following prior studies (e.g., $[99,100])$.

Table 1 summarizes the variables included in the empirical models, and Table 2 displays the correlation relationship between variables.

Table 1. Summary statistics.

\begin{tabular}{lccccc}
\hline \multicolumn{1}{c}{ Variable } & Obs. & Mean & Std. Dev. & Min & Max \\
\hline New Product Development & 2125 & 0.22 & 0.41 & 0 & 1 \\
Process Innovation & 2125 & 0.21 & 0.41 & 0 & 1 \\
Administrative Innovation & 2125 & 0.21 & 0.41 & 0 & 1 \\
Talent Program & 2125 & 0.15 & 0.35 & 0 & 1 \\
Work Autonomy & 2125 & 2.59 & 0.63 & 1 & 4 \\
Firm Size & 2125 & 10.30 & 2.16 & 2.83 & 17.93 \\
ROA & 2125 & 0.06 & 0.28 & -0.59 & 11.94 \\
Debt Ratio & 2125 & 0.57 & 0.37 & 0.00 & 5.34 \\
Sales Growth & 2125 & 0.14 & 2.08 & -0.94 & 66.69 \\
\hline
\end{tabular}

Table 2. Correlation matrix.

\begin{tabular}{|c|c|c|c|c|c|c|c|c|c|}
\hline & & 1 & 2 & 3 & 4 & 5 & 4 & 5 & 6 \\
\hline 1 & New Product Development & 1 & & & & & & & \\
\hline 2 & Process Innovation & $0.48 *$ & 1 & & & & & & \\
\hline 3 & Administrative Innovation & $0.35 *$ & $0.62 *$ & 1 & & & & & \\
\hline 4 & Talent Development & $0.17^{*}$ & $0.27 *$ & $0.26 *$ & 1 & & & & \\
\hline 5 & Work Autonomy & 0.01 & 0.00 & $0.04 *$ & 0.08 * & 1 & & & \\
\hline 6 & Firm Size & $0.22 *$ & $0.27 *$ & 0.26 * & 0.28 * & -0.03 & 1 & & \\
\hline 7 & ROA & 0.03 & 0.02 & 0.02 & -0.02 & 0.01 & $-0.15 *$ & 1 & \\
\hline 8 & Debt Ratio & -0.00 & 0.02 & 0.02 & -0.02 & -0.01 & $-0.09 *$ & $-0.06 *$ & 1 \\
\hline 9 & Sales Growth & $0.07^{*}$ & 0.03 & 0.03 & 0.00 & 0.00 & 0.00 & 0.01 & -0.01 \\
\hline
\end{tabular}

Note: * $p<0.05$. 


\section{Empirical Analysis and Results}

We employed an ordinary least squares regression model with the fixed effect estimators to test our prediction, and STATA 13 was utilized to run the statistical model. Table 3 displays the empirical results for the effect of innovation on product development. Models (1) and (2) show the significant positive effect of Process Innovation and Administrative Innovation on New Product Development, respectively. Model (3) also shows similar results, which supports Hypotheses 1 and 2. Our empirical analysis implied that firms' attempts to innovate their business processes or structures support sustainable product development.

Table 3. Regression analysis: The effect of innovation on product development.

\begin{tabular}{lccc}
\hline \multirow{2}{*}{ Variable } & \multicolumn{2}{c}{ Dependent Variable: New Product Development } \\
\cline { 2 - 4 } & Model (1) & Model (2) & Model (3) \\
\hline Process Innovation & $0.434^{* * *}$ & & $0.388^{* * *}$ \\
& $(21.729)$ & & $(15.833)$ \\
Administrative Innovation & & $0.303^{* * *}$ & $0.078^{* * *}$ \\
Firm Size & & $(14.456)$ & $(3.193)$ \\
& $0.013^{* * *}$ & $0.019^{* * *}$ & $0.012^{* * *}$ \\
Financial Performance & $(3.172)$ & $(4.318)$ & $(2.755)$ \\
& $0.064^{* *}$ & $0.076^{* * *}$ & $0.061^{* *}$ \\
Debt Ratio & $(2.298)$ & $(2.579)$ & $(2.173)$ \\
Sales Growth & -0.003 & 0.000 & -0.006 \\
& $(-0.137)$ & $(0.008)$ & $(-0.270)$ \\
Industry Effect & $0.010^{* * *}$ & $0.011^{* * *}$ & $0.010^{* * *}$ \\
Constant & $(2.793)$ & $(2.774)$ & $(2.744)$ \\
& Controlled & Controlled & Controlled \\
Observations & 0.021 & 0.006 & 0.034 \\
R-squared & $(0.432)$ & $(0.107)$ & $(0.698)$ \\
\hline
\end{tabular}

Note: t-statistics in parentheses. ${ }^{* * *} p<0.01,{ }^{* *} p<0.05,{ }^{*} p<0.1$.

Table 4 presents the empirical results for the moderating effect of HR practices in promoting the effect of innovation on new product development. Models (1) and (2) showed that the effect of process innovation on new product development was strengthened when firms have a talent-focused development program and higher work autonomy in the workplace. Similarly, Models (3) and (4) showed that administrative innovation was more effective in terms of new product development when firms had a talent development program and higher work autonomy. The results support hypotheses 3 and 4 .

We utilized STATA13's postestimation command, lincom (linear combinations of estimators), which provides the odds ratio of two variables in question. An odds ratio is a relative measure of the effect size of two variables. Followings are the results. Process innovation had a higher influence on new product development than talent development as the odds ratio was $1.715(p<0.00)$. Process innovation had a higher influence on new product development than work autonomy as the odds ratio was $1.325(p<0.00)$. Administrative innovation had a higher influence on new product development than talent development as the odds ratio was $1.456(p<0.00)$. Administrative innovation had a higher influence on new product development than work autonomy as the odds ratio was $1.329(p<0.00)$. The size above $1 \mathrm{implies}$ the higher \% of odds of new product development in the process/administrative innovation than HR practices. 
Table 4. Regression analysis: The moderating effect of HR practices.

\begin{tabular}{|c|c|c|c|c|}
\hline \multirow{2}{*}{ Variable } & \multicolumn{4}{|c|}{ Dependent Variable: Product Innovation } \\
\hline & Model (1) & Model (2) & Model (3) & Model (4) \\
\hline Process Innovation & $\begin{array}{l}0.394^{* * *} \\
(16.972)\end{array}$ & $\begin{array}{c}0.180^{* *} \\
(2.196)\end{array}$ & & \\
\hline Process Innovation * Talent Development & $\begin{array}{c}0.146^{* * *} \\
(3.154)\end{array}$ & & & \\
\hline Process Innovation * Work Autonomy & & $\begin{array}{c}0.096^{* * *} \\
(3.133)\end{array}$ & & \\
\hline Administrative Innovation & & & $\begin{array}{c}0.267^{* * *} \\
(10.917)\end{array}$ & $\begin{array}{c}0.252 * * * \\
(2.884)\end{array}$ \\
\hline Administrative Innovation * Talent Development & & & $\begin{array}{c}0.110^{* *} \\
(2.235)\end{array}$ & \\
\hline Administrative Innovation * Work Autonomy & & & & $\begin{array}{c}0.016 \\
(0.484)\end{array}$ \\
\hline Talent Development & $\begin{array}{c}-0.037 \\
(-1.239)\end{array}$ & $\begin{array}{c}0.025 \\
(1.050)\end{array}$ & $\begin{array}{c}0.017 \\
(0.535)\end{array}$ & $\begin{array}{c}0.061 * * \\
(2.478)\end{array}$ \\
\hline Work Autonomy & $\begin{array}{c}0.007 \\
(0.528)\end{array}$ & $\begin{array}{c}-0.015 \\
(-1.074)\end{array}$ & $\begin{array}{c}0.002 \\
(0.180)\end{array}$ & $\begin{array}{c}-0.003 \\
(-0.204)\end{array}$ \\
\hline Firm Size & $\begin{array}{c}0.012 * * * \\
(2.886)\end{array}$ & $\begin{array}{c}0.013^{* * *} \\
(2.949)\end{array}$ & $\begin{array}{c}0.017 * * * \\
(3.702)\end{array}$ & $\begin{array}{c}0.017^{* * *} \\
(3.710)\end{array}$ \\
\hline Financial Performance & $\begin{array}{c}0.067^{* *} \\
(2.384)\end{array}$ & $\begin{array}{c}0.061^{* *} \\
(2.191)\end{array}$ & $\begin{array}{c}0.078^{* * *} \\
(2.626)\end{array}$ & $\begin{array}{c}0.075^{* *} \\
(2.547)\end{array}$ \\
\hline Debt Ratio & $\begin{array}{c}-0.002 \\
(-0.071)\end{array}$ & $\begin{array}{c}-0.003 \\
(-0.151)\end{array}$ & $\begin{array}{c}0.001 \\
(0.032)\end{array}$ & $\begin{array}{c}-0.000 \\
(-0.016)\end{array}$ \\
\hline Sales Growth & $\begin{array}{c}0.010 * * * \\
(2.805)\end{array}$ & $\begin{array}{c}0.011^{* * *} \\
(2.877)\end{array}$ & $\begin{array}{c}0.011 * * * \\
(2.791)\end{array}$ & $\begin{array}{c}0.011^{* * *} \\
(2.805)\end{array}$ \\
\hline Industry Effect & Controlled & Controlled & Controlled & Controlled \\
\hline Constant & $\begin{array}{c}0.018 \\
(0.295)\end{array}$ & $\begin{array}{c}0.066 \\
(1.074)\end{array}$ & $\begin{array}{c}0.022 \\
(0.341)\end{array}$ & $\begin{array}{c}0.031 \\
(0.472)\end{array}$ \\
\hline Observations & 2125 & 2125 & 2125 & 2125 \\
\hline R-squared & 0.264 & 0.264 & 0.188 & 0.186 \\
\hline
\end{tabular}

Note: $\mathrm{t}$-statistics in parentheses. ${ }^{* * *} p<0.01,{ }^{* *} p<0.05,{ }^{*} p<0.1$.

\section{Discussion and Conclusions}

Organizational sustainability has received considerable management research attention for the past 20 years, and it emphasizes an organization's longer-term success rather than short-term performance. New product development is generally considered as one of the important goals since it benefits society with the innovative products, which in turn allows the firm to have a more durable market presence. Understanding the relationship between organizational innovation and new product development is important as it is not about how to earn more financial gains, rather it is about how to achieve sustainable market participation. Although a firm's attempt to introduce a new offering to the market is important, scholars have paid little attention to the role of innovation in business processes, and organizational structure in creating a new product.

The two main research goals of the present study are: (1) to explore and (2) examine the effect of process and administrative innovation on new product development and the supporting role of HR practices that support innovation. Our empirical findings reveal that organizational innovation increased the likelihood of achieving new product development goals. Existing literature has been mainly focused on the effect of technological innovation or product development specific process innovation on product development (e.g., [7-10]). This is majorly due to the fact that prior research has put most of the emphasis on the role of technological innovation in strengthening the competitiveness, based on a resource-based view which majorly asserts the importance of having resources that are rare, valuable, durable, non-substitutable, inimitable, and appropriable [101-103]. Our findings extend the current literature by showing the importance of organizational innovation on new product development. In this study, we propose that the introduction of process and administrative innovation also serves the resource-based view perspective, as management, and organizational process/system 
may also be firms' important sustainable competitive advantage. Thus, we can conclude that increasing organizational efficiency allows the firm to increase its sustainable presence in the product market.

\subsection{Theoretical Contribution and Implications}

First, our results enhance the understanding of the effect of process and administrative innovations on new product development. In innovation research on product development, we have less understanding of organizational innovation. Damanpour [41] suggested that organization innovation is a non-technological innovation, while innovation has been primarily conceptualized as a technology-based phenomenon. While advancement in technological resources has been argued to be important for the type of competitiveness that leads to new product development, we propose, and show, the value of innovating an organization's way of doing business. This suggests that organizational sustainability is largely determined by how the organization innovates its internal systems and processes to strengthen the efficiency and effectiveness of an organization's daily operations. Our empirical findings are in line with the Edquist et al. [104] and Sanidas [105], in that organizational change is often a cue for technological innovation. Second, our findings on the moderating effects of HR practices imply that the combined effect of process and administrative innovation and constructive HR practices are the most effective way to develop a new product. The external change, that is, process change or administrative structural change, may act as a basic mechanism that allows for a favorable outcome; how employees utilize such a system significantly changes the effectiveness of the innovation attempts. Our results suggest that considering HR practices in examining the effectiveness of innovation may help to better understand the overall effect of an innovation-related attempt in an organization. Third, while prior operations management and supply chain management studies have suggested that external relationships, for example, with supply chain partners [106-109] or customers [110-113], play an important role in achieving new product development, we explore how an organization's internal attempts to increase efficiency and improve human resource utilization matter for the development of new products. Complementary resources or new insights from the external environment may guide organizations in improving sustainability. However, efforts devoted to improving the internal environment are important antecedents of organizational sustainability.

\subsection{Practical Contribution and Implications}

First, our findings suggest that managers should be aware of the importance of increasing efficiency in daily organizational operations. Focusing only on improving technological resources may be an inefficient way to increase organizational sustainability as improvement in an organization's processes and systems nurtures an environment in which employees can utilize resources efficiently. While having a technical ability is an obvious pre-condition for new product development, not all firms with such advanced technical ability successfully develop new products. Our results imply that organizational efficiency achieved through the process and administrative innovation is an important factor for organizational sustainability. However, it is easier for managers to understand the importance of technological innovation on product development, as technology capabilities have been suggested as a core competency of organizations. That is one of the reasons why prior literature also has been mostly focusing on technological innovation [10,11]. To attempt organizational innovation, organizations should expect tangible results, but merely having a goal of developing a new product may not be sufficient enough to convince. Firms are in need of changing their structures or processes may execute organizational innovation, and it may benefit the firm to have ability related to a new product development. Second, our results on the joint effectiveness of the process and administrative innovation and high-quality HR practices in achieving new product development suggest that innovation-supportive HR practices will maximize the benefits of such innovation. Even though innovation attempts are meaningful by themselves, adequately supporting employees who are working toward business projects can change the outcome. Managers should be aware that changes to processes and organizational systems are the external system changes that employees are 
responsible for implementing. In addition, the implication of our findings is that the role of talent is specifically important for new product development, or innovation. In devising HR practices that promote innovation activities in organizations, it is more efficient to prioritize talent in resource allocation. Furthermore, our empirical results show that a creative work environment can be nurtured when employees are given higher levels of work autonomy. Our findings do not suggest that higher work autonomy is beneficial for all organizational activities, but rather highlights its importance in innovative activity.

\subsection{Limitation of the Study and Agenda for Future Research}

Our study is not without limitations. First, we utilized cross-sectional data, which provides a limited time scope. Follow up studies may test the proposed theoretical model using longitudinal data. The accumulation of innovative activities may provide larger benefits in developing new products. Second, while the intensity of innovation may differ among firms, we utilized a binary variable that does not address such differences. Further study may consider other factors that influence the intensity of innovation, such as different characteristics of industry or business cycle. However, our approach also offers value as it is difficult to find organizations that develop the same process or administrative innovations, as all organizations have different structures and systems. Our approach is an efficient way to measure an organization's successful attempt to change its current processes and administrative structure/system. Third, new product development is a variable that captures the introduction of a new product to the market, but it does not reflect the actual market performance of that new product. While we focus on new product development itself, the success of that new product may provide an additional view on the effect of process and administrative innovation. Fourth, while we show the influence of process and administrative innovations on new product development, the next step of this study should test the joint effect of technological and process/administrative innovations.

Author Contributions: Conceptualization, H.C.; formal analysis, methodology, and validation, H.C.; writing-original draft preparation, H.C., P.L., and C.H.S.; writing-review and editing, P.L. and C.H.S.; funding acquisition, H.C.; project administration, P.L. and C.H.S.

Funding: This research received no external funding.

Acknowledgments: This research was supported by the Korea University Research Grant.

Conflicts of Interest: The authors declare no conflict of interest.

\section{References}

1. Kim, W.; Park, J. Examining structural relationships between work engagement, organizational procedural justice, knowledge sharing, and innovative work behavior for sustainable organizations. Sustainability 2017, 9, 205. [CrossRef]

2. Blum-Kusterer, M.; Hussain, S.S. Innovation and corporate sustainability: An investigation into the process of change in the pharmaceuticals industry. Bus. Strategy Environ. 2001, 10, 300-316. [CrossRef]

3. Farr, J.L.; West, M.A. (Eds.) Innovation and Creativity at Work: Psychological and Organizational Strategies; Wiley: Chichester, UK, 1990.

4. Silvestre, B.S. A hard nut to crack! Implementing supply chain sustainability in an emerging economy. J. Clean. Prod. 2015, 96, 171-181. [CrossRef]

5. Ahlstrom, D. Innovation and growth: How business contributes to society. Acad. Manag. Perspect. 2010, 24, $11-24$.

6. Baumol, W. Red-queen games: Arms races, rule of law and market economies. J. Evol. Econ. 2004, 14, 237-247. [CrossRef]

7. Guan, J.C.; Yam, R.C.; Mok, C.K.; Ma, N. A study of the relationship between competitiveness and technological innovation capability based on DEA models. Eur. J. Oper. Res. 2006, 170, 971-986. [CrossRef]

8. Camisón, C.; Villar-López, A. Organizational innovation as an enabler of technological innovation capabilities and firm performance. J. Bus. Res. 2014, 67, 2891-2902. [CrossRef] 
9. Evangelista, R.; Vezzani, A. The economic impact of technological and organizational innovations. A firm-level analysis. Res. Policy 2010, 39, 1253-1263. [CrossRef]

10. Cooper, R.G. The drivers of success in new-product development. Ind. Mark. Manag. 2019, 76, 36-47. [CrossRef]

11. Noke, H.; Hughes, M. Climbing the value chain: Strategies to create a new product development capability in mature SMEs. Int. J. Oper. Prod. Manag. 2010, 30, 132-154. [CrossRef]

12. Laosirihongthong, T.; Prajogo, D.I.; Adebanjo, D. The relationships between firm's strategy, resources and innovation performance: Resources-based view perspective. Prod. Plan. Control 2014, 25, 1231-1246. [CrossRef]

13. Perdomo-Ortiz, J.; Gonzalez-Benito, J.; Galende, J. The intervening effect of business innovation capability on the relationship between Total Quality Management and technological innovation. Int. J. Prod. Res. 2009, 47, 5087-5107. [CrossRef]

14. Zhou, K.Z.; Wu, F. Technological capability, strategic flexibility, and product innovation. Strateg. Manag. J. 2010, 31, 547-561. [CrossRef]

15. Terziovski, M. Innovation practice and its performance implications in small and medium enterprises (SMEs) in the manufacturing sector: A resource-based view. Strateg. Manag. J. 2010, 31, 892-902. [CrossRef]

16. Liao, J.; Kickul, J.R.; Ma, H. Organizational dynamic capability and innovation: An empirical examination of internet firms. J. Small Bus. Manag. 2009, 47, 263-286. [CrossRef]

17. Sanz-Valle, R.; Jiménez-Jiménez, D. HRM and product innovation: Does innovative work behaviour mediate that relationship? Manag. Decis. 2018, 56, 1417-1429. [CrossRef]

18. Moorman, C. Organizational market information processes: Cultural antecedents and new product outcomes. J. Mark. Res. 1995, 32, 318-335. [CrossRef]

19. Andersson, M.; Karlsson, C. Knowledge in regional economic growth-The role of knowledge accessibility. Ind. Innov. 2007, 14, 129-149. [CrossRef]

20. Kyläheiko, K.; Jantunen, A.; Puumalainen, K.; Saarenketo, S.; Tuppura, A. Innovation and internationalization as growth strategies: The role of technological capabilities and appropriability. Int. Bus. Rev. 2011, 20, 508-520. [CrossRef]

21. Fu, X.; Pietrobelli, C.; Soete, L. The role of foreign technology and indigenous innovation in the emerging economies: Technological change and catching-up. World Dev. 2011, 39, 1204-1212. [CrossRef]

22. Maidique, M.A.; Zirger, B.J. A study of success and failure in product innovation: The case of the US electronics industry. IEEE Trans. Eng. Manag 1984, EM-31, 192-203. [CrossRef]

23. Athaide, G.A.; Klink, R.R. Managing seller-buyer relationships during new product development. J. Prod. Innov. Manag. 2009, 26, 566-577. [CrossRef]

24. Patanakul, P.; Chen, J.; Lynn, G.S. Autonomous teams and new product development. J. Prod. Innov. Manag. 2012, 29, 734-750. [CrossRef]

25. Yan, T.; Dooley, K. Buyer-supplier collaboration quality in new product development projects. J. Supply Chain Manag. 2014, 50, 59-83. [CrossRef]

26. Brockman, B.K.; Rawlston, M.E.; Jones, M.A.; Halstead, D. An exploratory model of interpersonal cohesiveness in new product development teams. J. Prod. Innov. Manag. 2010, 27, 201-219. [CrossRef]

27. Chien, S.H.; Chen, J.J. Supplier involvement and customer involvement effect on new product development success in the financial service industry. Serv. Ind. J. 2010, 30, 185-201. [CrossRef]

28. Schimmoeller, L.J. Success factors of new product development processes. Adv. Prod. Eng. Manag. 2010, 5, $25-32$.

29. Jaworski, B.J.; Kohli, A.K. Market orientation: Antecedents and consequences. J. Mark. 1993, 57, 53-70. [CrossRef]

30. Lynn, G.S.; Akgün, A.E. Innovation strategies under uncertainty: A contingency approach for new product development. Eng. Manag. J. 1998, 10, 11-18. [CrossRef]

31. Tatikonda, M.V.; Rosenthal, S.R. Successful execution of product development projects: Balancing firmness and flexibility in the innovation process. J. Oper. Manag. 2000, 18, 401-425. [CrossRef]

32. Chen, K.H.; Wang, C.H.; Huang, S.Z.; Shen, G.C. Service innovation and new product performance: The influence of market-linking capabilities and market turbulence. Int. J. Prod. Econ. 2016, 172, 54-64. [CrossRef]

33. Takeishi, A. Bridging inter-and intra-firm boundaries: Management of supplier involvement in automobile product development. Strateg. Manag. J. 2001, 22, 403-433. [CrossRef] 
34. Carr, A.S.; Kaynak, H. Communication methods, information sharing, supplier development and performance: An empirical study of their relationships. Int. J. Oper. Prod. Manag. 2007, 27, 346-370. [CrossRef]

35. Cousins, P.D.; Lawson, B.; Petersen, K.J.; Handfield, R.B. Breakthrough scanning, supplier knowledge exchange, and new product development performance. J. Prod. Innov. Manag. 2011, 28, 930-942. [CrossRef]

36. Hsu, C.C.; Tan, K.C.; Kannan, V.R.; Keong Leong, G. Supply chain management practices as a mediator of the relationship between operations capability and firm performance. Int. J. Prod. Res. 2009, 47, 835-855. [CrossRef]

37. Chesbrough, H. The logic of open innovation: Managing intellectual property. Calif. Manag. Rev. 2003, 45, 33-58. [CrossRef]

38. Coviello, N.E.; Joseph, R.M. Creating major innovations with customers: Insights from small and young technology firms. J. Mark. 2012, 76, 87-104. [CrossRef]

39. Gruner, K.E.; Homburg, C. Does customer interaction enhance new product success? J. Bus. Res. 2000, 49, 1-14. [CrossRef]

40. Joshi, A.W.; Sharma, S. Customer knowledge development: Antecedents and impact on new product performance. J. Mark. 2004, 68, 47-59. [CrossRef]

41. Damanpour, F. Footnotes to research on management innovation. Organ. Stud. 2014, 35, 1265-1285. [CrossRef]

42. Haneda, S.; Ito, K. Organizational and human resource management and innovation: Which management practices are linked to product and/or process innovation? Res. Policy 2018, 47, 194-208. [CrossRef]

43. Mokhber, M.; Khairuzzaman, W.; Vakilbashi, A. Leadership and innovation: The moderator role of organization support for innovative behaviors. J. Manag. Organ. 2018, 24, 108-128. [CrossRef]

44. Armbruster, H.; Bikfalvi, A.; Kinkel, S.; Lay, G. Organizational innovation: The challenge of measuring non-technical innovation in large-scale surveys. Technovation 2018, 28, 644-657. [CrossRef]

45. Birkinshaw, J.; Hamel, G.; Mol, M.J. Management innovation. Acad. Manag. Rev. 2008, 33, 825-845. [CrossRef]

46. Damanpour, F.; Aravind, D. Managerial innovation: Conceptions, processes and antecedents. Manag. Organ. Rev. 2012, 8, 423-454. [CrossRef]

47. Volberda, H.W.; Van Den Bosch, F.A.; Heij, C.V. Management innovation: Management as fertile ground for innovation. Eur. Manag. Rev. 2013, 10,1-15. [CrossRef]

48. Chen, C.J.; Huang, J.W. Strategic human resource practices and innovation performance-The mediating role of knowledge management capacity. J. Bus. Res. 2009, 62, 104-114. [CrossRef]

49. O'Reilly, C.A.; Pfeffer, J. Cisco Systems: Acquiring and retaining talent in hypercompetitive markets. People Strategy 2000, 23, 38-52.

50. Grant, J.L. Seeking Talent for Creative Cities: The Social Dynamics of Innovation; University of Toronto Press: Toronto, ON, Canada, 2014.

51. Van Esch, E.; Wei, L.Q.; Chiang, F.F. High-performance human resource practices and firm performance: The mediating role of employees' competencies and the moderating role of climate for creativity. Int. J. Hum. Resour. Manag. 2018, 29, 1683-1708. [CrossRef]

52. Lau, C.M.; Ngo, H. The HR system, organizational culture, and product innovation. Int. Bus. Rev. 2004, 13, 685-703. [CrossRef]

53. Ettlie, J.E.; Reza, E.M. Organizational integration and process innovation. Acad. Manag. J. 1992, 35, $795-827$. [CrossRef]

54. Knight, K.E. A descriptive model of the intra-firm innovation process. J. Bus. 1967, 40, 478-496. [CrossRef]

55. Utterback, J.M.; Abernathy, W.J. A dynamic model of process and product innovation. Omega 1975, 3, 639-656. [CrossRef]

56. OECD; Eurostat. Oslo Manual: Guidelines for Collecting and Interpreting Innovation Data, 3rd ed.; OECD Publishing: Paris, France, 2005.

57. Chang, J.; Bai, X.; Li, J.J. The influence of leadership on product and process innovations in China: The contingent role of knowledge acquisition capability. Ind. Mark. Manag. 2015, 50, 18-29. [CrossRef]

58. Najafi-Tavani, S.; Najafi-Tavani, Z.; Naudé, P.; Oghazi, P.; Zeynaloo, E. How collaborative innovation networks affect new product performance: Product innovation capability, process innovation capability, and absorptive capacity. Ind. Mark. Manag. 2018, 73, 193-205. [CrossRef]

59. Damanpour, F.; Gopalakrishnan, S. The dynamics of the adoption of product and process innovations in organizations. J. Manag. Stud. 2001, 38, 45-65. [CrossRef] 
60. Cummings, T.G.; Srivastva, S. Management of Work: A Socio-Technical Systems Approach; Comparative Administration Research Institute, Kent State University Press: Kent, OH, USA, 1997.

61. Damanpour, F.; Evan, W.M. Organizational innovation and performance: The problem of "organizational lag". Adm. Sci. Q. 1984, 29, 392-409. [CrossRef]

62. Roberts, E.B. Managing invention and innovation. Res. Technol. Manag. 1988, 31, 11-29. [CrossRef]

63. Tyre, M.; von Hippel, E. Locating Adaptive Learning: The Situated Nature of Adaptive Learning in Organizations; Working Paper 90-93; International Center for Research on the Management of Technology, MIT: Cambridge, MA, USA, 1993.

64. Eisenhardt, K.M.; Martin, J.A. Dynamic capabilities: What are they? Strateg. Manag. J. 2000, 21, $1105-1121$. [CrossRef]

65. Huang, K.F.; Dyerson, R.; Wu, L.Y.; Harindranath, G. From temporary competitive advantage to sustainable competitive advantage. Br. J. Manag. 2015, 26, 617-636. [CrossRef]

66. Abdi, K.; Senin, A.A. Investigation on the impact of organizational culture on organization innovation. J. Manag. Policies Pract. 2014, 2, 1-10.

67. Amabile, T.M. A model of creativity and innovation in organizations. Res. Organ. Behav. 1988, 10, $123-167$.

68. Roberts, E.B.; Fusfeld, A.R. Staffing the innovative technology-based organization. Sloan Manag. Rev. 1981, $22,19$.

69. James, W.M. Best HR practices for today's innovation management. Res. Technol. Manag. 2002, 45, 57-60. [CrossRef]

70. Collings, D.G.; Mellahi, K. Strategic talent management: A review and research agenda. Hum. Resour. Manag. Rev. 2009, 19, 304-313. [CrossRef]

71. Beugelsdijk, S. Strategic human resource practices and product innovation. Organ. Stud. 2008, 29, 821-847. [CrossRef]

72. Lepak, D.P.; Snell, S.A. The human resource architecture: Toward a theory of human capital allocation and development. Acad. Manag. Rev. 1999, 24, 31-48. [CrossRef]

73. Kang, S.-C.; Morris, S.S.; Snell, S.A. Relational archetypes, organizational learning, and value creation: Extending the human resource architecture. Acad. Manag. Rev. 2007, 32, 236-256. [CrossRef]

74. Drucker, P. Management Challenges for the 21st Century; HarperCollins: New York, NY, USA, 1999.

75. Sanchez, R. Strategic flexibility in product competition. Strateg. Manag. J. 1995, 16, 135-159. [CrossRef]

76. Griffin, M.A.; Neal, A.; Parker, S.K. A new model of work role performance positive behavior in uncertain and interdependent contexts. Acad. Manag. J. 2007, 50, 327-347. [CrossRef]

77. Bhatnagar, J. Talent management strategy of employee engagement in Indian ITES employees: Key to retention. Empl. Relat. 2007, 29, 640-663. [CrossRef]

78. Huselid, M.A.; Beatty, R.W.; Becker, B.E. 'A players' or 'A positions'? The strategic logic of workforce management. Harv. Bus. Rev. 2005, 83, 110-117. [PubMed]

79. Ashton, C.; Morton, L. Managing talent for competitive advantage: Taking a systemic approach to talent management. Strategic HR Rev. 2005, 4, 28-31. [CrossRef]

80. Boudreau, J.W.; Ramstad, P.M. Beyond HR: The New Science of Human Capital; Harvard Business Press: Boston, MA, USA, 2007.

81. Cappelli, P. Talent management for the twenty-first century. Harv. Bus. Rev. 2008, 86, 74. [PubMed]

82. Makarova, I.; Shubenkova, K.; Pashkevich, A. Development of an Intelligent Human Resource Management System in the Era of Digitalization and Talentism. In Proceedings of the 2018 18th International Conference on Mechatronics-Mechatronika (ME), Brno, Czech Republic, 5-7 December 2018; pp. 1-6.

83. Michaels, E.; Handfield-Jones, H.; Axelrod, B. The War for Talent; Harvard Business Press: Boston, MA, USA, 2001.

84. Joyce, W.F.; Slocum, J.W. Top management talent, strategic capabilities, and firm performance. Organ. Dyn. 2012, 41, 183-193. [CrossRef]

85. Peng, S.L.; Cherng, B.L.; Chen, H.C.; Lin, Y.Y. A model of contextual and personal motivations in creativity: How do the classroom goal structures influence creativity via self-determination motivations? Think. Skills Creat. 2013, 10, 50-67. [CrossRef]

86. Mumford, M.D.; Gustafson, S.B. Creativity syndrome: Integration, application, and innovation. Psychol. Bull. 1988, 103, 27-43. [CrossRef] 
87. Zhu, W.; Avolio, B.J.; Walumbwa, F.O. Moderating role of follower characteristics with transformational leadership and follower work engagement. Group Organ. Manag. 2009, 34, 590-619. [CrossRef]

88. Lumpkin, G.T.; Cogliser, C.C.; Schneider, D.R. Understanding and measuring autonomy: An entrepreneurial orientation perspective. Entrep. Theory Pract. 2009, 33, 47-69. [CrossRef]

89. Volmer, J.; Spurk, D.; Niessen, C. Leader-member exchange (LMX), job autonomy, and creative work involvement. Leadersh. Q. 2012, 23, 456-465. [CrossRef]

90. Liu, D.; Chen, X.P.; Yao, X. From autonomy to creativity: A multilevel investigation of the mediating role of harmonious passion. J. Appl. Psychol. 2011, 96, 294-309. [CrossRef]

91. Korean Labor Institute. The Workplace Panel Survey 2015; Korea Labor Institute: Seoul, Korea, 2015.

92. Forés, B.; Camisón, C. Does incremental and radical innovation performance depend on different types of knowledge accumulation capabilities and organizational size? J. Bus. Res. 2016, 69, 831-848. [CrossRef]

93. Chaney, P.K.; Devinney, T.M. New product innovations and stock price performance. J. Bus. Financ. Account 1992, 19, 677-695. [CrossRef]

94. Hoskisson, R.E.; Hitt, M.A.; Johnson, R.A.; Grossman, W. Conflicting voices: The effects of institutional ownership heterogeneity and internal governance on corporate innovation strategies. Acad. Manag. J. 2002, 45, 697-716.

95. Acharya, V.; Xu, Z. "Financial dependence and innovation: The case of public versus private firms". J. Financ. Econ. 2017, 124, 223-243. [CrossRef]

96. Santos, D.F.L.; Basso, L.F.C.; Kimura, H.; Kayo, E.K. Innovation efforts and performances of Brazilian firms. J. Bus. Res. 2014, 67, 527-535. [CrossRef]

97. Aghion, P.; Bond, S.; Klemm, A.; Marinescu, I. Technology and financial structure: Are innovative firms different? J. Eur. Econ. Assoc. 2004, 2, 277-288. [CrossRef]

98. Uhlaner, L.M.; van Stel, A.; Duplat, V.; Zhou, H. Disentangling the effects of organizational capabilities, innovation and firm size on SME sales growth. Small Bus. Econ. 2013, 41, 581-607. [CrossRef]

99. Chen, H.L.; Hsu, W.T. Family ownership, board independence, and R\&D investment. Fam. Bus. Rev. 2009, $22,347-362$.

100. Chrisman, J.J.; Patel, P.J. Variations in R\&D investments of family and non-family firms: Behavioral agency and myopic loss aversion perspectives. Acad. Manag. J. 2012, 55, 976-997.

101. Amit, R.; Schoemaker, P.J. Strategic assets and organizational rent. Strateg. Manag. J. 1993, 14, $33-46$. [CrossRef]

102. Barney, J.B. Resource-based theories of competitive advantage: A ten-year retrospective on the resource-based view. J. Manag. 2001, 27, 643-650. [CrossRef]

103. Peteraf, M.A. The cornerstones of competitive advantage: A resource-based view. Strateg. Manag. J. 1993, 14, 179-191. [CrossRef]

104. Edquist, C.; Hommen, L.; McKelvey, M.D. Innovation and Employment: Process versus Product Innovation; Edward Elgar Publishing: Cheltenham, UK, 2001.

105. Sanidas, E. Organizational Innovations and Economic Growth: Organosis and Growth of Firms, Sectors, and Countries; Edward Elgar Publishing: Cheltenham, UK, 2005.

106. Swink, M. Threats to new product manufacturability and the effects of development team integration processes. J. Oper. Manag. 1999, 17, 691-709. [CrossRef]

107. Petersen, K.J.; Handfield, R.B.; Ragatz, G.L. Supplier integration into new product development: Coordinating product, process and supply chain design. J. Oper. Manag. 2005, 23, 371-388. [CrossRef]

108. Yoo, S.H.; Shin, H.; Park, M.S. New product development and the effect of supplier involvement. Omega 2015, 51, 107-120. [CrossRef]

109. Yan, T.; Kull, T.J. Supplier opportunism in buyer-supplier new product development: A China-US study of antecedents, consequences, and cultural/institutional contexts. Decis. Sci. 2015, 46, 403-445. [CrossRef]

110. Chang, W.; Taylor, S.A. The effectiveness of customer participation in new product development: A meta-analysis. J. Mark. 2016, 80, 47-64. [CrossRef]

111. Brockhoff, K. Customers' perspectives of involvement in new product development. Int. J. Technol. Manag. 2003, 26, 464-481. [CrossRef] 
112. Cooper, R.G.; Kleinschmidt, E.J. New Products: The Key Factors in Success; Marketing Classics Press: Chicago, IL, USA, 2011.

113. Cui, A.S.; Wu, F. The impact of customer involvement on new product development: Contingent and substitutive effects. J. Prod. Innov. Manag. 2017, 34, 60-80. [CrossRef]

(C) 2019 by the authors. Licensee MDPI, Basel, Switzerland. This article is an open access article distributed under the terms and conditions of the Creative Commons Attribution (CC BY) license (http://creativecommons.org/licenses/by/4.0/). 